\title{
GOALS AND OUTCOMES OF SLOW TOURISM: CASE STUDY OF VOJVODINA PROVINCE
}

\author{
Tamara Božović \\ Jovana Miljković \\ Karmen Mikulić
}

https://doi.org//10.20867/tosee.06.9

\begin{abstract}
Purpose - Numerous new forms aimed at meeting the sophisticated needs of modern consumers characterize tourism, as one of the fastest growing sectors in the world. In such conditions, the concept of slow tourism gained importance accompanied with a strong need to slow down the pace of life. The aim of this paper is, in addition to explaining this phenomenon, to examine the manner of travel when visiting slow destinations in the autonomous province of Vojvodina, as well as to determine the goals and outcomes of tourist visits.

Methodology - For the purposes of the research, authors form list of goals, outcomes and mode of travel. The list of goals and outcomes expected after the trip in the questionnaire was taken and adjusted to the scale applied by the authors Oh, Assaf and Baloglu (2016), while authors introduced some question to the last segment of questions about the mode of travel.

Findings - Based on the results, it is concluded that the ways of travel of slow tourists are largely related to the goals and outcomes of tourists who visited Vojvodina, and all tourists included in this study are highly satisfied with Vojvodina as a slow destination.

Contribution - The contribution of this study is reflected in the fact that slow tourism has not been sufficiently researched in Vojvodina, and this study is significant because it initiated research on this topic, which can be a great potential of this region.
\end{abstract}

Keywords: slow tourism, slow destinations, consumer behaviour, goals of travel, outcomes of travel, Autonomous Province of Vojvodina.

\section{INTRODUCTION}

The character of slow tourism as a relatively new form of tourism is becoming more, present in the tourism market, and still provides researchers with a lot of space to study. Some of them addressed the first theoretical aspects and set the framework for this form of tourism (eg, Parkins and Craig 2006; Lumsdon and McGrath 2011; Fullagar, Markwell and Wilson 2012; Groenendaal 2012; Howard 2012; Lipman and Murphy 2012; Moore 2012; Guiver and McGrath 2016; Valls, Mota, Vieira, and Santos 2019; Serdane 2020; Lunić et al. 2020). Until now, the focus of researchers has been mainly on the conceptual definition and definition of slow tourism as a new form of tourism, while research on the motivation, goals and ways of travel of slow tourists has only become relevant in recent years (Oh et al. 2016). As the issue of goals and outcomes of slow tourism consumers has not been sufficiently researched so far, this research will contribute to the research of this topic and present Vojvodina as a destination suitable for the development of slow tourism. Also, so far it has not been clearly explained what exactly motivates tourists to travel "slowly" and what they actually strive for during their trip (Oh et al. 2016). The contribution of the presented research is reflected in the fact 
ToSEE - Tourism in Southern and Eastern Europe, Vol. 6, pp. 125-135, 2021.

T. Božović, J. Miljković, K. Mikulić: GOALS AND OUTCOMES OF SLOW TOURISM: CASE STUDY ...

that it will show what are the goals of travel of slow tourists in Vojvodina and what the outcomes that occur after the trip are. In addition, the connection between the way of traveling (slow / fast travel) and the destinations, and later the outcome of the tourist trip, will be presented. Numerous elements of slow tourism appear in Vojvodina, although the label itself is rarely used for any purpose, and with this paper, we intend to show the potential of Vojvodina for the development of the concept of slow tourism and its recognition among tourists.

\section{LITERATURE REVIEW}

\subsection{The Concept of Slow Tourism}

Slow tourism is becoming an increasingly well-known term both in the literature on destination planning and in advertising in general. Nevertheless, although the term "slow tourism" is often used, there does not seem to be a defined clear and scientifically validated term (Valls et al. 2019). The authors Oh and associates (2016) agree with this, and they believe that there is no real and unique definition of slow tourism. On the other hand, the authors Dickinson and Lumsdon (2010) define slow tourism as: "Conceptual framework that includes tourists who travel "slower" and closer to their home destination, while staying longer at a selected destination and using sustainable and local forms of transport, consuming food specific to the place where they visit, etc.". According to the definition of Dickinson and Lumsdon (2010), many other authors (Caffyn, 2007; 2012; Yurtseven and Kaya 2011; Đuranović et al. 2019) state that the basic principles on which slow tourism is based: devoting some time to a destination that is visited through getting to know people, culture, traditions and surroundings. The author Georgica (2015) agrees with all definitions above, stating that according to the philosophy of slow travel, it is more important to get to know one, smaller place in detail than to get to know superficially more different areas.

\subsection{Slow vs Fast Travel Mode}

Immediately after the industrial revolution, the world suddenly "accelerated" and began to transform drastically. The transformation in the world after the revolution was also reflected in travel (Khan 2015). By increasing the speed of travel, tourists often fail to experience many of the essential values of the destination and thus miss quality experiences while traveling. The same observations are shared by the authors Markwell, Fullagar and Wilson (2012), who believe that tourists do not have enough interest in learning, getting to know the people and cultures of the destinations they visit, as well as less respect for the natural environment. The opposite of this way of traveling is slow tourism, which as a form of alternative tourism advocates for the experience of tourists, slowing down, preserving the environment, and increasing the quality of the tourist experience.

According to some authors (Buckley 2011; Yurtseven and Kaya 2011), the principles of slow tourism are to set aside time and attach to a specific destination through participating in activities, respecting and nurturing connections with locals and the place. 
ToSEE - Tourism in Southern and Eastern Europe, Vol. 6, pp. 125-135, 2021.

T. Božović, J. Miljković, K. Mikulić: GOALS AND OUTCOMES OF SLOW TOURISM: CASE STUDY ...

Many other authors agree with this, stating that slow tourism refers not only to speed but also to "overall slowdown", and slow tourism is characterized by the use of slow transportation, participation in activities of tourists with slow and weak impact and establishing slow and significant interactions (Gardener 2009; Dickinson and Lumptson 2011; Heitmann, Robinson and Povey 2011). Authors Dickinson and Peeters (2014) believe that a fast way of traveling can represent "time savings" and a slow mode of travel "enjoying time".

\section{METHODOLOGY}

\section{Sample}

The sample consisted of 243 respondents, and their socio-demographic characteristics are shown in Table 1.

Table 1: Socio-demographic characteristics of respondents $(n=\mathbf{2 4 3})$

\begin{tabular}{|c|c|c|c|}
\hline Gender & Percentage (\%) & Age & Percetage (\%) \\
\hline Male & 28.4 & $<18$ age & 1.2 \\
\hline Female & 71.6 & 19-30 age & 48.1 \\
\hline Education & & $31-40$ age & 19.3 \\
\hline Primary school & 0 & 41-60 age & 28.8 \\
\hline High school & 23.9 & $>61$ age & 2.5 \\
\hline Faculty & 46.9 & & \\
\hline Master studies & 24.7 & & \\
\hline PhD studies & 4.5 & & \\
\hline Income & Percentage (\%) & Type of residence & Percentage (\%) \\
\hline Below average & 31.3 & Village & 10.7 \\
\hline Average income & 26.3 & $\begin{array}{l}\text { Small town (up to } \\
10,000 \text { inhabitants) }\end{array}$ & 11.5 \\
\hline Above average & 26.7 & $\begin{array}{c}\text { Medium-sized city } \\
(10,000-100,000 \\
\text { inhabitants })\end{array}$ & 25.1 \\
\hline No income & 15.6 & $\begin{array}{l}\text { Big city (over } 100,000 \\
\text { inhabitants) }\end{array}$ & 52.7 \\
\hline
\end{tabular}

Source: author's work

Table 1 shows that a larger share of respondents who participated in the survey are women (71.6\%), the age that most belongs to the category of 19-30 years (48.1\%). In addition, the respondents are mostly highly educated people living in big cities.

\section{Procedure}

The research was conducted from April to August 2020. An online (Google Docs) questionnaire distributed via social networks (Facebook, LinkedIn, Instagram) was used as the main tool, while a number of respondents were surveyed in the classic way (paperpencil). 
ToSEE - Tourism in Southern and Eastern Europe, Vol. 6, pp. 125-135, 2021.

T. Božović, J. Miljković, K. Mikulić: GOALS AND OUTCOMES OF SLOW TOURISM: CASE STUDY ...

\section{Instrument}

For the purposes of the research, the following were formed: a list of two goals of the visit that the respondents had during the trip (self-discovery and revitalization), as well as three outcomes that are expected after the trip (satisfaction, return, recommendation). The list of goals and outcomes expected after the trip in the questionnaire was taken and adjusted to the scale applied by the authors Oh et al. (2016). The last list of claims consists of 13 questions related to the way of traveling and staying in the destination. Some questions were taken from the author Oh et al. (2016), while the authors introduced some questions. The questions were formed after a detailed review of the literature of previous research and with the help of attributes (Valls et al. 2019) that describe slow tourism. These are the attributes: alternative to mass tourism (Heitman el al. 2011; Molz 2009; Özdemir and Çelebi 2018), local character (Marson 2011; Chen and Rahman 2018), cultural character (Caffyn 2012; Hernández-Mogollón, Duarte and FolgadoFernández 2018), sustainability (Lowry and Lee 2011; Lumsdon and McGrath 2011), authenticity (Dickinson et al., 2011), and others. Data collected by the survey were processed through the program IBM SPSS 17 (descriptive statistical analysis, t-test, ANOVA test, correlation analysis).

\section{RESULTS AND DISCUSSION}

In the following segments, a five-point Likert scale was used (1 - I completely disagree, 2 - I partially disagree, 3 - I am not sure, 4 - I partially agree, 5 - I completely agree). The first question of the second segment was related to the frequency of travel. Most respondents stated that they travel once in several months $(45.3 \%)$ while $25.3 \%$ of respondents travel once a month. This result is important for the research because it shows that the group of surveyed tourists is authoritative for the survey, given that tourists travel frequently. This question was followed by a question about the motives and reasons for visiting one of the destinations in Vojvodina (Table 2).

Table 2: The main reason for visiting the destination of slow tourism in Vojvodina

\begin{tabular}{cc}
\hline Reason for visit & Percentage (\%) \\
\hline Holiday & 63,8 \\
Business & 9,1 \\
Visit to a friend / family & 20.2 \\
Excursion / picnic & 3.3 \\
Field teaching & 2.1 \\
School excursion & 1.6 \\
\hline
\end{tabular}

Source: author's work

As the main reasons for visiting the destination, the respondents mostly mentioned vacation $(63.8 \%)$ and this data speaks in favor of the fact that Vojvodina is a destination that associates people with rest, relaxation and enjoyment. The fact that $48.6 \%$ of respondents stayed in only one destination during their visit to Vojvodina, while only $12.8 \%$ visited more than three destinations, speaks in favor of Vojvodina having great potential as a slow destination (Table 3). In addition, it is not surprising that the 
ToSEE - Tourism in Southern and Eastern Europe, Vol. 6, pp. 125-135, 2021.

T. Božović, J. Miljković, K. Mikulić: GOALS AND OUTCOMES OF SLOW TOURISM: CASE STUDY ...

respondents mostly travel with a partner or family $(54.3 \%)$, while a small number of respondents travel alone $(11.5 \%)$ or in a group $(6.2 \%)$.

Table 3: Number of visits to destinations during the stay in Vojvodina

\begin{tabular}{cc}
\hline I stayed during the trip & Percentage (\%) \\
\hline Only in one destination & 48.6 \\
I visited two or three destinations & 38.6 \\
I have visited more than three destinations & 12.8 \\
\hline
\end{tabular}

Source: author's work

\section{Descriptive statistical analysis}

In order to conclude whether the respondents were really "slow tourists" while staying at the destination, the author introduced a segment of questions related to the ways of traveling and behavior during the stay at the destination. Although slow travel is not usually associated with fast travel, it may contain some of its elements, especially when it comes to means of transport and technology (Germann Molz 2009; Markwell et al. 2012; Serdane 2017). So we see from the results that most travelers organized their own travel, while a small number of respondents traveled in an organized manner (eg through a travel agency). In addition, when looking at the offer of slow tourism, it is noticed that the media and information technologies play a key role in the promotion of this type of tourism (Conway and Timms, 2010 2012), so more than half of respondents (3.1) booked their accommodation outside the hotel, through platforms that are available online.

It is interesting to note that respondents on the one hand stated that they tried to visit and see as much as possible at the destination during their stay (4) which is a model of "fast" travel, while on the other hand they stated that they traveled at their own pace (4) represents a model of "slow" travel. Based on this data, it can be concluded that the respondents do not want to miss anything at the destination, but at the same time they stay at their pace of travel and do not need to hurry. According to some authors (Oh et al. 2016; Serdane 2017), slow and fast ways of traveling should be viewed in the light of complementing each other, not excluding the other, because both can be used to achieve slow travel goals. This is supported by the fact that the respondents stated that they would rather explore the destination on their own (3.9) than want to visit all the most popular destinations (3.7). A large number of respondents at the destination consumed local products, while a slightly smaller number bought some of the local souvenirs. To date, few studies have been conducted that include both fast and slow modes of travel as a mentally instrumental process toward achieving certain travel goals (Urieli, Ionai and Simchai 2002; Oh et al. 2016). Most studies that have been conducted on similar topics determine the way of traveling according to the means of movement, ie. vehicles (Lew and McKercher 2006; Dickinson and Peeters 2014), and this research makes some contribution to the research of this topic. The obtained data can confirm the position that the respondents are familiar with the term slow tours and that according to the way they travel and stay at the destination, it can be concluded that the respondents are really "slow tourists". 
ToSEE - Tourism in Southern and Eastern Europe, Vol. 6, pp. 125-135, 2021.

T. Božović, J. Miljković, K. Mikulić: GOALS AND OUTCOMES OF SLOW TOURISM: CASE STUDY ...

Table 4: Results of descriptive statistical analysis on the mode of travel and stay at the destination of slow tourism in Vojvodina

\begin{tabular}{|c|c|c|}
\hline Way of travel and stay at the destination & Mean & $\begin{array}{l}\text { Standard } \\
\text { deviation }\end{array}$ \\
\hline \multicolumn{3}{|l|}{ Slow way of travel } \\
\hline (ST1) I organized my own trip. & 3.8 & 1.5697 \\
\hline \multirow{2}{*}{$\begin{array}{l}\text { (ST2) I planned my trip in detail in advance. } \\
\text { (ST3) I have booked accommodation that is not a hotel (airbnb, } \\
\text { booking ...). }\end{array}$} & 3.4 & 1.3987 \\
\hline & 3.1 & 1.7212 \\
\hline (ST4) I traveled at my own pace (self-organizing tours, breaks, etc.). & 4 & 1.3887 \\
\hline $\begin{array}{c}\text { (ST5) During the trip, I reduced the use of social networks (facebook, } \\
\text { instagram ...). }\end{array}$ & 3.8 & 1.1934 \\
\hline $\begin{array}{l}\text { (ST6) During my stay at the destination I consumed local products } \\
\text { (food, drinks ..). }\end{array}$ & 4.1 & 1.2457 \\
\hline \multirow{3}{*}{$\begin{array}{l}\text { (ST7) During the trip I bought some of the local souvenirs. } \\
\text { (ST8) I researched the destination myself during my stay. } \\
\text { (ST9) During my stay at the destination I used local transport, walking, } \\
\text { etc. for transport? }\end{array}$} & 3.6 & 1.4454 \\
\hline & 3.9 & 1.3396 \\
\hline & 3.4 & 1.5268 \\
\hline \multicolumn{3}{|l|}{$\begin{array}{l}\text { Fast way of travel } \\
\end{array}$} \\
\hline \multirow{2}{*}{$\begin{array}{c}\text { (FT1) I traveled in an organized way (eg travel agency). } \\
\text { (FT2) I tried to visit and see as much as possible at the destination } \\
\text { during my stay. }\end{array}$} & 2.1 & 1.5736 \\
\hline & 4 & 1.2022 \\
\hline $\begin{array}{l}\text { (FT3) I tried to do as many things as possible at the destination during } \\
\text { my stay. }\end{array}$ & 3.8 & 1.2582 \\
\hline $\begin{array}{l}\text { (FT4) During the trip, it was important for me to visit all the most } \\
\text { popular attractions in the destination. }\end{array}$ & 3.7 & 1.1934 \\
\hline
\end{tabular}

Source: author's work

In order to determine the factors that represent the most important goals as well as the outcomes after the trip, a descriptive statistical analysis was conducted. In the following table (Table 5), each factor is shown separately, through mean values and standard deviations for each statement. As the most valuable goal, the respondents state revitalization, ie. a claim that they felt fulfilled after the trip (4.4). The data from the table prove that Vojvodina justified the expectations and met the motives of the respondents to visit one of its destinations. All travel outcomes have a high mean (min. 4.3). Almost all respondents confirmed that they are satisfied with their stay in Vojvodina, that they will visit it again and that they will talk about the destination as a positive experience through a recommendation to others. It is concluded that Vojvodina is a real destination of slow tourism tailored to the respondents who visited it.

Table 5: Results of descriptive statistical analysis on travel goals and outcomes in slow tourism destinations in Vojvodina

\begin{tabular}{ccc}
\hline Travel goals & Mean & $\begin{array}{c}\text { Standard } \\
\text { deviation }\end{array}$ \\
\hline Self-discovery & $\mathbf{4}$ & 1.01088 \\
(G1) The trip to the destination recovered - "It charged my batteries." & 4.3 & 1.0535 \\
(G2) After the trip, I felt much better and more balanced. & 4.3 & 1.0922 \\
(G3) The trip allowed me to enrich the complete picture of myself. & 3.5 & 1.2834 \\
Revitalization & $\mathbf{4 . 4}$ & .9956 \\
(G4) I felt fulfilled after the trip. & 4.4 & .9956 \\
\hline
\end{tabular}


ToSEE - Tourism in Southern and Eastern Europe, Vol. 6, pp. 125-135, 2021.

T. Božović, J. Miljković, K. Mikulić: GOALS AND OUTCOMES OF SLOW TOURISM: CASE STUDY ...

Table 5 (continued)

\begin{tabular}{ccc}
\hline Outcomes after travel & Mean & $\begin{array}{c}\text { Standard } \\
\text { deviation }\end{array}$ \\
\hline Satisfaction & $\mathbf{4 . 3}$ & .9819 \\
(O1) I am satisfied with the trip to the destination in Vojvodina. & 4.3 & .9819 \\
Re-arrival & $\mathbf{4 . 2}$ & 1.0512 \\
(O2) I will again choose to travel to Vojvodina to the same destination. & 4 & 1.1583 \\
(O3) I will again choose to travel to Vojvodina to visit another destination. & 4.3 & 1.0876 \\
Recommendation & $\mathbf{4 . 4}$ & 1.0178 \\
(O4) I will recommend Vojvodina as a destination to others. & 4.4 & 1.0461 \\
(O5) I will talk about Vojvodina as a positive experience. & 4.4 & 1.0323 \\
\hline
\end{tabular}

Source: author's work

In addition to a descriptive presentation, it is important to show the relationship between the mode of travel (slow / fast) and the goals and outcomes of the trip. The following table (Table 6) presents a correlation analysis between slow and fast travel modes and each travel destination and outcome. It can be observed that there is a positive correlation between goals and outcomes and all slow travel factors. Also, it is noticed that the correlation is very strong, which means that the slower the tourists traveled, the more they achieved their goals (self-discovery and revitalization) and were more satisfied with the outcomes of the trip. Observing the fast way of traveling, it can be noticed that there is no correlation only related to tourists who traveled in an organized way, that is. through a travel agency. Other correlations are positive, which is confirmed by the previously stated, that in many segments the slow and fast way of traveling permeates and that they cannot be separated from each other.

Table 6: Results of correlation analysis according to the goals and outcomes of tourists in relation to their ways of traveling

\begin{tabular}{|c|c|c|c|c|c|c|c|c|c|}
\hline & G1 & G2 & G3 & G4 & 01 & $\mathrm{O2}$ & $\mathbf{O 3}$ & 04 & O5 \\
\hline ST1 & $.490^{*}$ & $.405^{*}$ & $.247 *$ & $.415^{*}$ & $.382 *$ & $.309 *$ & $.370^{*}$ & $.395^{*}$ & $.381^{*}$ \\
\hline ST2 & $.431^{*}$ & $.405^{*}$ & $.298 *$ & $.405^{*}$ & $.369 *$ & $.295^{*}$ & $.358 *$ & $.369 *$ & $.355^{*}$ \\
\hline ST3 & $.264 *$ & $.252^{*}$ & .141 & $.214^{*}$ & $.227 *$ & $.210^{*}$ & $.199 *$ & $.189 *$ & $.151^{*}$ \\
\hline ST4 & $.548^{*}$ & $.481^{*}$ & $.293^{*}$ & $.495^{*}$ & $.494^{*}$ & $.331 *$ & $.469 *$ & $.479 *$ & $.487^{*}$ \\
\hline ST5 & $.573^{*}$ & $.513^{*}$ & $.382^{*}$ & $.565^{*}$ & $.528^{*}$ & $.423^{*}$ & $.456^{*}$ & $.495^{*}$ & $.503^{*}$ \\
\hline ST6 & $.590 *$ & $.556^{*}$ & $.386^{*}$ & $.606^{*}$ & $.558 *$ & $.490^{*}$ & $.564^{*}$ & $.564 *$ & $.565^{*}$ \\
\hline ST7 & $.474^{*}$ & $.463^{*}$ & $.361 *$ & $.428 *$ & $.445^{*}$ & $.390^{*}$ & $.351 *$ & $.399 *$ & $.391 *$ \\
\hline ST8 & $658^{*}$ & $.614^{*}$ & $.440^{*}$ & $.658 *$ & $.618^{*}$ & $.485^{*}$ & $.590^{*}$ & $.635^{*}$ & $.603^{*}$ \\
\hline ST9 & $.410^{*}$ & $.414^{*}$ & $.479^{*}$ & $.418^{*}$ & $.387 *$ & $.363^{*}$ & $.392 *$ & $.433^{*}$ & $.382^{*}$ \\
\hline FT1 & -.033 & .005 & $.175^{*}$ & .039 & -.023 & .066 & .020 & -.024 & -.009 \\
\hline FT2 & $.563^{*}$ & $.547^{*}$ & $.324 *$ & $.576^{*}$ & $.505^{*}$ & $.501 *$ & $.482 *$ & $.518 *$ & $.504^{*}$ \\
\hline FT3 & $.504^{*}$ & $.492 *$ & $.466^{*}$ & $.527 *$ & $.476^{*}$ & $.445^{*}$ & $.469 *$ & $.487 *$ & $.435^{*}$ \\
\hline FT4 & $.407 *$ & $.421 *$ & $.325^{*}$ & $.442 *$ & $.361^{*}$ & $.352^{*}$ & $.334^{*}$ & $.406^{*}$ & $.358^{*}$ \\
\hline
\end{tabular}

$* \mathrm{p}<0.0$

Source: author's work 
ToSEE - Tourism in Southern and Eastern Europe, Vol. 6, pp. 125-135, 2021.

T. Božović, J. Miljković, K. Mikulić: GOALS AND OUTCOMES OF SLOW TOURISM: CASE STUDY ...

\section{T test}

T-test was performed to determine potential differences in responses between men and women. Statistically significant differences were observed in one travel destination and in one tourist travel outcome.

Namely, it is women who largely believe that their journey has recovered, that is, recharged their batteries $(t=-1.990, \mathrm{p}=.049)$ and women to a greater extent believe that they will again choose to travel to Vojvodina to the same destination $(\mathrm{t}=-2.470, \mathrm{p} .=.015)$.

\section{ANOVA test}

The application of the ANOVA test was based on determining statistically significant differences in the goals and outcomes of tourists' travel, and in relation to their annual travel frequency, the reason for visiting Vojvodina, the company they traveled in and the number of destinations they visited when visiting Vojvodina. Observing the annual frequency of travel, as well as the reason for visiting Vojvodina, no statistically significant differences were observed according to what their goals were and what the outcomes of the trip were. Statistically significant differences in the responses of tourists were observed in relation to who the tourists traveled with. Differences were not observed in travel goals, but only in two post-travel outcomes.

Table 7: ANOVA test results

\begin{tabular}{ccc}
\hline Factors & F-value & $\begin{array}{c}\text { LSD post- } \\
\text { hoc test }\end{array}$ \\
\hline I am satisfied with the trip to the destination in Vojvodina. & 1.964 & $/$ \\
I will choose again to travel to Vojvodina to the same destination. & $2.669 *$ & $1<3,4$ \\
I will again choose to travel to Vojvodina, to visit another destination. & $2.938 *$ & $1<2,3,4$ \\
I will recommend Vojvodina as a destination to others. & 1.455 & $/$ \\
I will talk about Vojvodina as a positive experience. & 2.306 & $/$ \\
\hline p $<0.05$ & & \\
Source: author's work & &
\end{tabular}

Based on the presented analysis, it can be noticed that tourists who traveled alone, will obviously decide to travel to Vojvodina to the same or another destination to a lesser extent, than tourists who traveled with a partner, family or friend. Also, statistically significant differences were observed depending on how many destinations tourists visited in Vojvodina.

Table 8: ANOVA test results

\begin{tabular}{ccc}
\hline Factors & F-value & $\begin{array}{c}\text { LSD post- } \\
\text { hoc test }\end{array}$ \\
\hline I am satisfied with the trip to the destination in Vojvodina. & 1.664 & $/$ \\
I will choose again to travel to Vojvodina to the same destination. & $3.981 *$ & $1,2<3$ \\
I will again choose to travel to Vojvodina, to visit another destination. & 2.230 & $/$ \\
I will recommend Vojvodina as a destination to others. & 1.373 & $/$ \\
I will talk about Vojvodina as a positive experience. & 2.004 & $/$ \\
\hline
\end{tabular}

$* \mathrm{p}<0.05$

Source: author's work 
ToSEE - Tourism in Southern and Eastern Europe, Vol. 6, pp. 125-135, 2021.

T. Božović, J. Miljković, K. Mikulić: GOALS AND OUTCOMES OF SLOW TOURISM: CASE STUDY ...

The only difference is that tourists who have visited more than three destinations in Vojvodina have a greater desire to visit Vojvodina again, than tourists who have visited a smaller number of destinations during their trip.

\section{CONCLUSION}

The study shows that the main goals for tourists are self-discovery and revitalization, and they travel accordingly. Also, it is important to note that all tourists involved in this study are very satisfied with Vojvodina as a slow destination, that they will return again and recommend it to friends. Based on the results of this study, tourists who visited Vojvodina can be described as slow tourists and enjoy slow tourist movements. This type of tourism offers a new vision and perspective for the development of tourism in this area.

Therefore, the results of this research can contribute to a deeper understanding of the concept of slow tourism in the literature, as well as the development potential of this type of tourism in Vojvodina, which can be applied in practice.

The contribution of the research is reflected in the formation and introduction of a new scale that examines the way of traveling, which was not the subject of previous research in the field of slow tourism.

The limitation of the study can be seen in the fact that it covers only the attitudes of domestic tourists, while future research may focus on foreign tourists in order to further compare the results.

\section{ACKNOWLEDGMENT}

The authors acknoweledge financial support of the Ministry of Education, Science and Technological Development of the Republic of Serbia (Grant No. 451-03-9/2021-14/200125)

\section{REFERENCES}

Buckley, R. (2011), “Tourism under Climate Change: Will slow travel supersede short breaks?", A Journal of the Human Environment, Vol. 40, No. 3, pp. 328-331. https://doi.org/10.1007/S13280-010-0100-X

Caffyn, A. (2007), "Slow Tourism", Tourism Society Journal, 133, pp. 10-16.

Caffyn, A. (2012), “Advocating and Implementing Slow Tourism”, Tourism Recreation Research, Vol. 37, No. 1, pp. 77-80. https://doi.org/10.1080/02508281.2012.11081690

Chen, H. and Rahman, I. (2018), "Cultural tourism: An analysis of engagement, cultural contact, memorable tourism experience and destination loyalty", Tourism Management Perspectives, Vol. 26, pp. 153163. https://doi.org/10.1016/j.tmp.2017.10.006

Conway, D. and Timms, B.F. (2010), "Re-branding alternative tourism in the Caribbean: The case for "slow tourism", Tourism and Hospitality Research, Vol. 10, No. 4, pp. 329-344. https://doi.org/10.1057/thr.2010.12

Conway, D. and Timms, B.F. (2012), “Are Slow Travel and Slow Tourism Misfits, Compadres or Differen Genres?", Tourism Recreation Research, Vol. 37, No. 1, pp. 71-76. https://doi.org/10.1080/02508281.2012.11081689

Dickinson, J. and Lumsdon, L. (2011), "Slow travel and tourism", Earthscan, London.

Dickinson, J.E. and Peeters, P. (2014), "Time, tourism consumption and sustainable development", International journal of tourism research, Vol. 16, No. 1, pp. 11-21. https://doi.org/10.1002/jtr.1893 
ToSEE - Tourism in Southern and Eastern Europe, Vol. 6, pp. 125-135, 2021.

T. Božović, J. Miljković, K. Mikulić: GOALS AND OUTCOMES OF SLOW TOURISM: CASE STUDY ...

Đuranović, D., Tomić, S., Leković, K. and Marić, D. (2019), "Slow tourism in Vojvodina-motives and goals of consumers", Zbornik radova Ekonomskog fakulteta u Istočnom sarajevu, Vol. 8, No. 18, pp. 4960. https://doi.org/10.7251/ZREFIS1918049D

Fullagar, S., Markwell, K. and Wilson, E. (Eds.) (2012), Slow tourism: Experiences and mobilities (Vol. 54), Channel View Publications.

Georgica, G. (2015), “The Tourist's Perception about Slow Travel-A Romanian Perspective", Procedia Economics and Finance, Vol. 23, pp. 1596-1601. https://doi.org/10.1016/S2212-5671(15)00557-2

Germann Molz, J. (2009), "Representing pace in tourism mobilities: staycations, Slow Travel and The Amazing Race", Journal of Tourism and Cultural Change, Vol. 7, No. 4, pp. 270-286. https://doi.org/10.1080/14766820903464242

Groenendaal, E. (2012), "Slow tourism initiatives: An exploratory study of Dutch lifestyles entrepreneurs in France", in Slow tourism: Experiences and mobilities, Vol. 54, pp. 201-213. https://doi.org/10.21832/9781845412821-017

Guiver, J. and McGrath, P. (2017), "Slow Tourism: Exploração de discursos", Dos Algarves: A Multidisciplinary e-Journal, Vol. 27, pp. 11-34, http://www.dosalgarves.com/rev/N27/2rev27.pdf

Heitmann, S., Robinson, P. and Povey, G. (2011), "Slow food, slow cities and slow tourism", in P. Robinson, S. Heitmann, and P. Dieke (Eds.), Research Themes for Tourism, CABI, Wallingford, pp.114-127. doi: 10.1079/9781845936846.0114

Hernández-Mogollón, J.M., Duarte, P.A. and Folgado-Fernández, J.A. (2018), “The contribution of cultural events to the formation of the cognitive and affective images of a tourist destination", Journal of Destination Marketing \& Management, Vol. 8, pp. 170-178. https://doi.org/10.1016/j.jdmm.2017.03.004

Howard, C. (2012), "Speeding up and slowing down: Pilgrimage and slow travel through time", in Slow tourism: Experiences and mobilities, pp. 11-24. https://doi.org/10.21832/9781845412821-004

Khan, S. (2015), "How slow is 'slow'? Dilemmas of Slow Tourism", TEAM Journal of Hospitality and Tourism, Vol. 12, No. 1, pp. 39-49. https://teamjournalht.files.wordpress.com/2015/12/teamjournal_121-2015_article-3_khan.pdf

Lew, A. and McKercher, B. (2006), "Modeling tourist movements: A local destination analysis", Annals of tourism research, Vol. 33, No. 2, pp. 403-423. https://doi.org/10.1016/j.annals.2005.12.002

Lipman, M.B. and Murphy, L. (2012), "Make haste slowly': Environmental sustainability and willing workers on organic farms", in Slow tourism: Experiences and mobilities, 54,84.

Lumsdon, L.M. and McGrath, P. (2011), "Developing a conceptual framework for slow travel: Agrounded theory approach", Journal of Sustainable Tourism, Vol. 19, No. 3, pp. 265-279. https://doi.org/10.1080/09669582.2010.519438

Lowry, L.L. and Lee, M. (2016), "CittaSlow, slow cities, slow food: Searching for a model for the development of slow tourism", https://scholarworks.umass.edu/cgi/viewcontent.cgi?article=1618\&context=ttra

Lunić, D., Micera, R., Stanišić, N., Radović, N., Savković, M., Vukic, D. and Alčaković, S. (2020), "The Covid-19 Pandemic and Slow Tourism", https://singipedia.singidunum.ac.rs/izdanje/43288-thecovid-19-pandemic-and-slow-tourism

Marson, D. (2011), "From mass tourism to niche tourism", Research themes for tourism, Vol. 1, No. 1, pp. 1-11.

Markwell, K., Fullagar, S. and Wilson, E. (2012), "Reflecting upon slow travel and tourism experiences", in Slow tourism: Experiences and mobilities, pp. 227-233. https://doi.org/10.21832/9781845412821-019

Moore, K. (2012), “On the Periphery of Pleasure: Hedonics, Eudaimonics, and Slow Travel”, in Slow tourism: Experiences and mobilities, Vol. 54, pp. 25-35.

Oh, H., Assaf, A.G. and Baloglu, S. (2016), "Motivations and goals of slow tourism", Journal of Travel Research, Vol. 55, No. 2, pp. 205-219. https://doi.org/10.1177/0047287514546228

Özdemir, G. and Çelebi, D. (2018), "Exploring dimensions of slow tourism motivation”, Anatolia, Vol. 29, No. 4, pp. 540-552. https://doi.org/10.1080/13032917.2018.1460854

Parkins, W. and Craig, G. (2006), Slow Living, University of New South Wales Press, Sydney.

Serdane, Z. (2017), "Slow tourism in slow countries: the case of Latvia“ (Doctoral dissertation), University of Salford, http://usir.salford.ac.uk/id/eprint/43513/

Serdane, Z. (2020), "Slow philosophy in tourism development in Latvia: The supply side perspective“, Tourism Planning \& Development, Vol. 17, No. 3, pp. 295-312. https://doi.org/10.1080/21568316.2019.1650103

Yurtseven, H.R. and Kaya, O. (2011), "Slow tourists: A comparative research based on Cittaslow principles", American International Journal of Contemporary Research, Vol. 1, No. 2, pp. 91-98. http://www.aijcrnet.com/journals/Vol_1_No_2_September_2011/12.pdf

Valls, J.F., Mota, L., Vieira, S.C.F. and Santos, R. (2019), "Opportunities for slow tourism in Madeira", Sustainability, Vol. 11, No. 17, 4534. https://doi.org/10.1080/09669582.2010.519438 
ToSEE - Tourism in Southern and Eastern Europe, Vol. 6, pp. 125-135, 2021.

T. Božović, J. Miljković, K. Mikulić: GOALS AND OUTCOMES OF SLOW TOURISM: CASE STUDY .

Tamara Božović, MSc, PhD student

University of Novi Sad, Faculty of Sciences-Department of Geography, Tourism and Hotel Management; Dositeja Obradovića Square 1, Novi Sad, Serbia

+381669160091

tamaraabozovic@gmail.com

Jovana Miljković, MSc, $\mathrm{PhD}$ student

University of Novi Sad, Faculty of Sciences-Department of Geography, Tourism and Hotel Management; Dositeja Obradovića Square 1, Novi Sad, Serbia

$+381628590208$

miljkovic.jovana.95@gmail.com

Karmen Mikulić, MA, PhD student

University or Rijeka, Faculty of Tourism and Hospitality Management

Department of Microeconomics and Macroeconomics

Primorska 46, 51410 Opatija, Croatia

+38551294758

karmenm@fthm.hr 